\title{
ANALISIS MEMBANGUN ORIENTASI PASAR USAHA KECIL DAN MENENGAH (UKM) MELALUI COMPETITIVE ADVANTAGE DALAM MENCAPAI KINERJA PEMASARAN (STUDI PADA UKM SENTRA BATIK SEMARANGAN DI KOTA SEMARANG)
}

\author{
Nadia Dwi Irmadiani \\ Fakultas Ekonomi Universitas Pakuan, Bogor \\ E-mail: nadianadio88@gmail.com
}

\begin{abstract}
Market orientation as a business philosophy can be defined by how an organization implements the concept of market orientation in its activities and behavior. Market orientation is one of the factors that influence competitive advantage. The competitive advantage could demonstrate the company's ability to achieve economic benefits in connection with the profits that can be achieved by competitors in the market within the same industry. While marketing performance is influenced by the environment of the company. Thus the success of a company can be seen from how it responses to the pressure from its environment in facing the competitive market. This research is aimed to analyse the market orientation of small, and medium scale business of superior product of batik Semarangan in Semarang through competitive advantage in achieving its marketing performance. The research is done in small, and medium scale business that create Semarangan batik in Semarang. It takes 40 small, and medium scale of business. The data is obtained by using questionnaire instrument while the variables influence is tested by using the path analysis. The result shows that market orientation has a positive influence to the competitive advantage and marketing performance. Meanwhile the competitive advantage has a positive influence to marketing performance. The research also finds the proof that competitive advantage is able to mediate the market orientation and marketing performance.
\end{abstract}

Keywords: Market Orientation, Competitive Advantage, and Marketing Performance

\section{PENDAHULUAN}

Era persaingan global yang semakin ketat dan terbuka merupakan fenomena yang harus dihadapi oleh pelaku usaha, salah satunya dengan menghasilkan produk yang memiliki daya saing kuat dan harga yang kompetitif. Keberadaan UKM sebagai salah satu kekuatan pendukung pergerakan perdagangan dalam negeri dan pendorong pembangunan ekonomi, memiliki peran yang sangat penting dan menentukan dalam rangka pemulihan ekonomi regional dan nasional terutama dalam menghadapi dampak krisis global yang melanda hampir seluruh negara di dunia. Dengan diberlakukannnya Asean-China Free Trade Area (AFTA), perdagangan dalam negeri bahkan diharapkan tidak hanya mampu menjadi penyelamat dari dampak krisis tersebut tetapi juga memiliki daya saing dengan produk atau barang-barang dari China. Sampai saat ini UKM telah memberikan kontribusi signifikan pada pendapatan daerah maupun pendapatan nasional. Hal ini menunjukkan bahwa UKM merupakan aspek penting dalam pembangunan ekonomi yang kompetitif.

Sejalan dengan era desentralisasi dan pengembangan ekonomi regional, otonomi daerah memberikan implikasi bagi daerah 
untuk merencanakan sendiri pembangunan di daerahnya dengan dukungan sumber daya lokal. Hal ini menjadikan posisi UKM sangat penting untuk mewujudkan pengembangan perekonomian daerah dan pemberdayaan masyarakat yaitu memberikan kontribusi besar pada pendapatan daerah provinsi seperti Provinsi Jawa Tengah khususnya kota Semarang.

Semarang merupakan salah satu kota besar di Indonesia yang telah berkembang dalam sektor perekonomiannya, seperti sektor perdagangan dan jasa. Semarang dapat menjadi salah satu sentra UKM yang dapat menopang perekonomian masyarakat dalam menjalankan fungsinya. Berkaitan dengan hal ini kota Semarang memiliki beberapa produk yang menjadi unggulan, atau icon Kota Semarang, yaitu lumpia, bandeng, dan batik khas semarangan.

Pemikiran yang melandasi adalah bahwa bisnis dan lingkungan umum memungkinkan sebuah perusahaan untuk mempelajari tentang peluang yang mungkin diperoleh untuk mengambil suatu keuntungan serta memperhitungkan kondisi yang dapat mengancam kinerja atau kelangsungan perusahaan (Calantone, 1994:9). Oleh karena itu pengusaha memiliki kesempatan merumuskan strategi kompetitif sesuai dengan kondisi lingkungannya. Hal ini ditunjukkan dengan fenomena yang terjadi pada lingkungan bisnis batik semarangan sebagai salah satu produk unggulan atau icon kota Semarang.

Penelitian ini bertujuan untuk menganalisis orientasi pasar usaha kecil dan menengah produk unggulan sentra batik Semarangan di Kota Semarang melalui competitive advantage dalam mencapai kinerja pemasarannya.

\section{KAJIAN PUSTAKA}

\section{Orientasi Pasar (Market Orientation)}

Orientasi pasar merupakan filosofi bisnis yang menjadi tujuan atau pernyataan mengenai kebijakan perusahaan. Orientasi pasar sebagai sebuah filosofi bisnis dapat diartikan dengan bagaimana organisasi mengimplementasikan konsep orientasi pasar dalam aktifitas dan perilaku organisasi tersebut. Oleh karena itu organisasi yang berorientasi pasar adalah organisasi yang tindakan-tindakannya konsisten dengan konsep pemasaran. Orientasi pasar ditentukan oleh tiga faktor pendukung yaitu manajemen senior, dinamika antar bagian, dan sistem organisasional.

Faktor manajemen senior menunjukkan bahwa manajer puncak bertanggung jawab terhadap nilai orientasi dan kepercayaan dari konsumen sehingga komitmen mereka sangat penting bagi pelaksanaan orientasi pasar. Faktor dinamika antar bagian adalah interaksi yang ada dalam organisasi baik formal maupun informal, seperti konflik, hubungan antar bagian, dan menghargai pendapat dan ide dari bagian lain, dan sistem organisasional adalah hal-hal yang berkaitan dengan struktur organisasi seperti departementalisasi, formalisasi dan sentralisasi.

Selain ditentukan oleh tiga faktor pendukung orientasi pasar juga memiliki tiga konsekuensi, yaitu respon konsumen, kinerja bisnis, dan respon pekerja. Respon konsumen adalah tugas organisasi untuk menciptakan kepuasan konsumen sehingga dengan sendirinya mereka akan selalu membeli produk-produk perusahaan. Kinerja bisnis berarti orientasi pasar membantu memperjelas fokus dan tujuan organisasi. Karena semakin baik orientasi pasar organisasi, semakin baik pula kinerja bisnisnya sedangkan respon pekerja menunjukkan semakin baik orientasi pasar organisasi, semakin besar pula semangat kelompok, kepuasan kerja, dan komitmen mereka terhadap perusahaan.

Sejauh mana kinerja bisnis sebagai salah satu konsekuensi orientasi pasar memilik dampak pada organisasi apakah mengalami

JIMFE (Jurnal Ilmiah Manajemen Fakultas Ekonomi)

Volume 2 No. 2 Tahun 2016, Hal. 58-68 
peningkatan atau penurunan dipengaruhi oleh dua moderator pendukung yaitu moderator sisi penawaran dan moderator sisi permintaan. Moderator sisi penawaran adalah hal-hal yang berkaitan dengan keadaan pasar yang tidak stabildan perubahan teknologi. Sedangkan untuk moderator sisi permintaan adalah hal-hal yang berhubungan dengan persaingan dan keadaan ekonomi pada umumnya. Dampak konsekuensi orientasi pasar terhadap kinerja bisnis menurut Nerver dan Slater ( 1990:2) adalah determinan yang penting bagi organisasi dan merupakan hubungan yang kuat diantara keduanya sehingga menghasilkan kinerja dan profitabilitas yang maksimal bagi organisasi.

Walaupun orientasi pasar merupakan konsep yang penting dalam strategi pemasaran dan semakin banyak perusahaan yang menerapkan konsep tersebut dalam kegiatannya, menurut Jaworski dan kohli (1993:3) belum terdapat alat ukur yang baku untuk mengukur orientasi pasar dan dampaknya bagi kinerja perusahaan. Dengan melakukan penelitian terhadap beberapa unit bisnis strategis (SBU), Kohli dkk. kemudian mengemukakan suatu konsep MARKOR (Market Orientation) yang berguna bagi organisasi di dalam mengukur orientasi pasar.

Market Orientation adalah konsep orientasi pasar yang menetapkan tingkat dimana sebuah unit bisnis strategis:

1. Terlibat dalam aktifitas peningkatan informasi pesan antar bagian dalam perusahaan.

2. Menyebarkan informasi baik secara vertikal maupun horisontal dengan melalui saluran yang formal dan infomal.

3. Mengembangkan serta mengimplementasikan program pemasaran dengan dasar peningkatan informasi pasar.
Selain ketiga faktor diatas, terdapat pula tiga karakter utama dari konsep pengukuran orientasi pasar, yaitu:

1. Fokus pada konsumen dari unit bisnis strategis dan usaha yang mengarah pada kebutuhan dan pilihan mereka.

2. Unsur-unsur yang berdasar pada aktifitas, bukan pada filosofi bisnis.

3. Batasan dari faktor orientasi pasar secara umum dan faktor komponen yang terkait.

\section{Competitive Advantage}

Keunggulan bersaing menurut Porter (2007:124) adalah kemampuan suatu perusahaan untuk meraih keuntungan ekonomis di atas laba yang mampu diraih oleh pesaing di pasar dalam industri yang sama. Perusahaan yang memiliki keunggulan kompetitif senantiasa memiliki kemampuan dalam memahami perubahan struktur pasar dan mampu memilih strategi pemasaran yang efektif. Studi yang dilakukan Porter selanjutnya menetapkan strategi generik yang diklasifikasikan dalam tiga kategori, yaitu cost leadership, diferensiasi, dan focus. Pilihan tiap-tiap perusahaan terhadap strategi generik di atas akan bergantung kepada analisis lingkungan usaha untuk menentukan peluang dan ancaman.

Keunggulan daya saing dapat juga diperoleh dengan berbagai cara, dengan menawarkan produk atau jasa baik minimum, dengan keunikan dibanding pesaingnya, atau memfokuskan diri pada segmen tertentu. Salah satu kunci keberhasilan perusahaan dalam lingkungan yang kompetitif adalah mengenali bagaimana mempertahankan keunggulan kompetitif. Menurut Porter (2007:22), dalam menciptakan keunggulan kompetitif seperti membuat pilihan sulit tentang apa yang akan lakukan dan tidak lakukan, sehingga keunggulan kompetitif biasanya didefinisikan sebagai kemampuan untuk pengembalian investasi secara 
konsisten di atas rata-rata untuk industri (Porter, 2007:23). Keunggulan bersaing merupakan sesuatu kondisi yang memiliki keunggulan yang unik, dan sulit untu ditiru (Porter,2007:35). Keunggulan kompetitif dapat dibuat dengan berbagai cara, misalnya dengan ukuran, lokasi, atau akses ke sumber daya.

Sumber daya dan kemampuan yang berharga, jarang, kurang imitable dan nonsubstitutable terdiri dari kompetensi perusahaan unik atau inti, sehingga menyajikan keunggulan kompetitif yang berkelanjutan. Keuntungan tersebut dikembangkan dari waktu ke waktu dan tidak mudah ditiru. Ini adalah penciptaan nilai bagi pelanggan, kelangkaan dibandingkan dengan ditiru, persaingan, dan organisasi.

\section{Kinerja Pemasaran}

Mengukur kinerja pemasaran merupakan kunci agar kegiatan pemasaran menjadi efektif dan efisien.Jika kita tidak melakukan pengkuran kinerja harus memberikan dasar terhadap pemahaman mengenai apa yang harus terjadi dengan kegiatan pemasaran dan memberikan sarana untuk perbaikan efektifitas, efisiensi, dan adaptabilitasnya.

Setiap perusahaan harus berkompetisi untuk memenangkan persaingan, dengan begitu suatu perusahaan dapat memiliki nilai tambah dalam mempertahankan pelanggan dan mencari pelanggan. Hal yang harus dilakukan perusahaan adalah memikirkan untuk mencapai keunggulan bersaing.

Kinerja pemasaran merupakan konsep untuk mengukur prestasi suatu perusahaan dalam pasar terhadap suatu produk, sebagai cermin dari keberhasilan usaha untuk memenangi persaingan pasar, strategi yang berkualitas untuk menimbulkan daya terima pelanggan terhadap tingkat kualitas, perbaikan pasar, dan kinerja. Untuk mencapai kesuksesan di pasar, tidak cukup mencari tenaga penjualnya saja melainkan mencari tenaga penjual yang mampu mendukungbagaimana menjaga hubungan baik antara perusahaan dengan pelanggan. Studi yang dilakukan Lamb (1998:5) menyatakan bahwa, tak jarang suatu perusahaan mengeluarkan sumber daya yang begitu besar untuk mengimplementasikan suatu strategi.

Sistem pemasaran memandang tingkat keberhasilan kinerja pemasaran yang dimiliki perusahaan diukur dari bertambahnya unit yang terjual dan bertambahnya jumlah pelanggan dalam mencapai target penjualan (dalam Ferdinand 2000:23). Tingkat kinerja pemasaran dapat diklasifikasikan menjadi tiga yaitu responsive marketing, anticipative marketing, dan need-shaping marketing.

1. Responsive marketing, Pemasaran didefinisikan sebagai tugas mencari dan mengisi kebutuhan. Ini adalah bentuk penghargaan dari pemasaran ketika ada kebutuhan yang jelas dan ketika beberapa perusahaan telah mengenali bentuk ini dan kemudian menyiapkan solusi yang dapat dilaksanakan.

2. Anticipative marketing

Ini adalah usaha lain untuk menghargai kebutuhan yang bersifat darurat atau tersembunyi.

\section{Need-shaping marketing}

Tingkat pemasaran yang paling berani terjadi ketika perusahaan mengenalkan sebuah produk atau jasa yang tidak pernah diminta oleh siapapun dan bahkan mungkin tidak pernah terbayangkan.

Kebanyakan perusahaan dikendalikan oleh pasar. Namun hal ini lebih bagus daripada dikendalikan oleh produk. Perusahaan yang dikendalikan pasar akan fokus dalam melakukan pencarian terhadap pelanggan yang ada dan untuk mengenali permasalahan mereka, mendapatkan ide-ide baru, dan melakukan pengujian produk yang

JIMFE (Jurnal Ilmiah Manajemen Fakultas Ekonomi)

Volume 2 No. 2 Tahun 2016, Hal. 58-68 
diajukan dan melakukan berbagai perubahan. Usaha mereka biasanya menghasilkan peningkatan, meski bukan berupa inovasi, sehingga dapat mencapai keunggulan yang kompetitif.

Kinerja pemasaran merupakan konstruk atau faktor yang umum digunakan untuk mengukur dampak dari sebuah strategi perusahaan.Strategi perusahaan selalu diarahkan untuk menghasilkan kinerja, baik berupa kinerja pemasaran (seperti volume penjualan, porsi pasar atau marketshare dan tingkat pertumbuhan penjualan) maupun kinerja keuangan (Ferdinand, 2000:5). Kualitas pemasaran dicirikan dengan: (1) Teknik-teknik pemasaran yang inovatif, (2) Penempatan tenaga kerja yang terampil, dan (3) Mengontrol jalur-jalur distribusi yang tepat (Marrison dan Roth, 1992: 473).

Konsep model teoritikal dasar yang dikembangkan oleh Ferdinand menjelaskan terdapat tiga bagian dalam modelnya. Bagian pertama memiliki dua titik yaitu internal dan eksternal. Titik internal meliputi sumber daya stratejik dan kapabilitas organisasional sedangkan titik eksternal meliputi orientasi pasar kompetitif dan adaptabilitas lingkungan statejik. Pada bagian kedua dari model ini adalah orientasi strategi yang dikembangkan perusahaan untuk menghasilkan kinerja keuangan dan kinerja pemasaran. Berdasarkan hal inilah suatu perusahaan dapat menemukan jalan untuk menciptakan dan meningkatkan bagian ketiga yaitu sustainable competitive advantage. Namun model yang digambarkan di atas barulah sebuah model teoritis yang dikembangan berdasarkan kajian teori sehingga membutuhkan langkah panjang dalam pembuktiannya. Agenda penelitian selanjutnya menyarankan supaya panelitian diarahkan untuk menjelaskan proses formulasi strategi yang mempertimbangkan penyiasatan adaptabilitas lingkungan dan orientasi pasar bersaing sehingga dapat menghasilkan kinerja pemasaran yang baik
(Ferdinand, 2006:111).

Berdasarkan hal diatas penelitian ini dilakukan untuk menjawab permasalahan, apakah terdapat pengaruh orientasi pasar terhadap competitive advantage produk unggulan UKM sentra batik semarangan? Kemudian apakah terdapat pengaruh orientasi pasar terhadap kinerja pemasaran produk unggulan UKM sentra batik semarangan? Serta apakah terdapat pengaruh competitive advantage terhadap kinerja pemasaran? Dengan demikian hipotesis dalam penelitian ini dirumuskan sebagai berikut:

$\mathrm{H}_{1}$ : Orientasi pasar berpengaruh positif terhadap competitive advantage.

$\mathrm{H}_{2}$ : Orientasi pasar berpengaruh positif terhadap kinerja pemasaran.

$\mathrm{H}_{3}$ : Competitive advantage berpengaruh positif terhadap kinerja.

\section{METODE PENELITIAN}

Penelitian menggunakan pendekatan kuantitatif dengan tipe explanatory, yaitu penelitian yang bermaksud menjelaskan pengaruh antara satu variabel dengan variabel yang lain (Sugiyono, 1999:11). Dalam penelitian ini dijelaskan analisis membangun orientasi pasar usaha kecil menengah (UKM) melalui competitive advantage dalam mencapai kinerja pemasaran studi pada UKM produk unggulan sentra batik semarangan di Kota Semarang, melalui pengujian hipotesis. Adapun pengaplikasian variabel-variabel tersebut adalah sebagai berikut:

1. $X_{1}$ (Orientasi pasar): Variabel independen

2. $Y_{1}$ (Competitive advantage): Variabel dependen

3. $Y_{2}$ (Kinerja pemasaran): Variabel dependen

Penelitian ini dilaksanakan di Sentra Batik Semarangan Kelurahan Rejomulyo serta 
yang tersebar di Kota Semarang lainnya. Objek penelitian difokuskan pada pengrajin batik itu sendiri sebagai pemilik UKM Batik Semarangan.

Variabel dikelompokkan menjadi dua, yaitu variabel independen (bebas) dan variabel dependen (terikat). Dalam penelitian ini yang menjadi variabel independen (bebas), yaitu orientasi pasar dan adaptabilitas lingkungan. Variabel dependen (terikat) adalah kinerja pemasaran dan keunggulan bersaing (competitive advantage) pada UKM produk unggulan Sentra Batik Semarangan di Kota Semarang.

a) Indikator orientasi pasar: Orientasi pelanggan, orientasi pesaing dan koordinasi antar fungsi.

b) Indikator competitive advantage: unik, harga bersaing, jarang dijumpai, tidak mudah ditiru dan tidak mudah diganti

c) Indikator kinerja pemasaran: pertumbuhan penjualan, porsi pasar atau market share, pertumbuhan pelanggan dan volume penjualan.
Sampel penelitian adalah pengrajin batik sebanyak 40 pemilik UKM produk unggulan Sentra Baik Semarangan, serta yang tersebar di seluruh Kota Semarang.

Metode analisis data yang digunakan dalam penelitian ini adalah analisis jalur (path analysis). Menurut Robert D. Rutherfor (1993) dalam Jonathan Sarwono (2006:185), analisis jalur (path analysis) adalah suatu teknik analisis untuk menganalisis hubungan sebab akibat yang terjadi pada regresi ganda jika variabel bebasnya mempengaruhi variabel tergantung tidak hanya secara langsung tetapi juga secara tidak langsung. Selain itu penelitian ini menggunakan software SPSS versi 20

\section{HASIL DAN PEMBAHASAN}

Validitas dan Reliabilitas Instrumen

Pengujian validitas dilakukan dengan menggunakan rumus korelasi product moment. Pengujian validitas selengkapnya dapat dilihat pada tabel berikut ini.

Tabel 1. Hasil Pengujian Validitas

\begin{tabular}{|c|c|c|c|c|}
\hline No & Indikator & $\mathbf{R}$ & $r$ tabel & Keterangan \\
\hline \multirow[t]{4}{*}{1} & Orientasi pasar & & & \\
\hline & - $\quad$ Indikator variabel 1 & 0,857 & 0,312 & Valid \\
\hline & - $\quad$ Indikator variabel 2 & 0,802 & 0,312 & Valid \\
\hline & - $\quad$ Indikator variabel 3 & 0,929 & 0,312 & Valid \\
\hline \multirow[t]{6}{*}{3} & Competitive advantage & & & \\
\hline & - $\quad$ Indikator variabel 1 & 0,880 & 0,312 & Valid \\
\hline & - $\quad$ Indikator variabel 2 & 0,933 & 0,312 & Valid \\
\hline & - $\quad$ Indikator variabel 3 & 0,886 & 0,312 & Valid \\
\hline & - $\quad$ Indikator variabel 4 & 0,850 & 0,312 & Valid \\
\hline & - Indikator variabel 5 & 0,903 & 0,312 & Valid \\
\hline \multirow[t]{5}{*}{4} & Kinerja pemasaran & & & \\
\hline & - $\quad$ Indikator variabel 1 & 0,692 & 0,312 & Valid \\
\hline & - $\quad$ Indikator variabel 2 & 0,789 & 0,312 & Valid \\
\hline & _ $\quad$ Indikator variabel 3 & 0,802 & 0,312 & Valid \\
\hline & - $\quad$ Indikator variabel 4 & 0,745 & 0,312 & Valid \\
\hline
\end{tabular}

Sumber : Data primer yang diolah, 2017

JIMFE (Jurnal Ilmiah Manajemen Fakultas Ekonomi)

Volume 2 No. 2 Tahun 2016, Hal. 58-68 
Tabel tersebut menunjukkan bahwa semua pertanyaan yang digunakan untuk mengukur variabel-variabel yang digunakan dalam penelitian ini mempunyai koefisien korelasi yang lebih besar dari $r_{\text {table }}=0,312$ (nilai $r$ tabel untuk $\mathrm{n}-2=40-2=38$ )

\section{Uji Realibilitas Instrumen}

Pengujian reliabilitas ini menggunakan rumus alpha Cronbach (Sugiyono, 2004:235). Pengujian reliabilitas dalam penelitian ini menggunakan rumus alpha. Hasil pengujian reliabilitas untuk masing-masing variabel diringkas pada tabel berikut ini:

Tabel 2. Hasil Pengujian Reliabilitas

\begin{tabular}{|l|c|c|}
\hline Variabel & Alpha & Keterangan \\
\hline Orientasi pasar $\left(\mathrm{X}_{1}\right)$ & 0,828 & Reliabel \\
Competitive advantage $\left(\mathrm{Y}_{1}\right)$ & 0,934 & Reliabel \\
Kinerja pemasaran $\left(\mathrm{Y}_{2}\right)$ & 0,752 & Reliabel \\
\hline
\end{tabular}

Sumber : Data primer yang diolah, 2017

Hasil uji reliabilitas tersebut menunjukkan bahwa semua variabel mempunyai koefisien alpha yang cukup besar yaitu diatas 0,60 sehingga dapat dikatakan masing-masing variabel dari kuesioner adalah reliabel.

\section{Hasil Analisis Jalur (Path Analysis)}

Pengujian analisis jalur dalam penelitian ini dilakukan dengan menggunakan pendekatan analisis regresi linier. Pengujian makna hubungan antar variabel yang dihipotesiskan dalam penelitian ini selanjutnya didasarkan pada 2 model analisis regresi linier.

\section{Model 1 Jalur I orientasi pasar $\left(\mathrm{X}_{1}\right)$ terhadap competitive advantage $\left(Y_{1}\right)$.}

Persamaan I menguji pengaruh orientasi pasar terhadap competitive advantage, dan diperoleh model persamaan sebagai berikut:

Persamaan model I

\begin{tabular}{|c|c|c|c|c|c|c|}
\hline & & \multicolumn{2}{|c|}{$\begin{array}{l}\text { Unstandardized } \\
\text { Coefficients }\end{array}$} & $\begin{array}{r}\text { Standardiz } \\
\text { ed Coefficients }\end{array}$ & \multirow[b]{2}{*}{$\mathrm{T}$} & \multirow[b]{2}{*}{ Sig. } \\
\hline \multicolumn{2}{|c|}{ Model } & B & Std. Error & Beta & & \\
\hline 1 & (Constant) & 5.373 & 1.768 & & 3.039 & .004 \\
\hline & $\begin{array}{l}\text { Orientasi } \\
\text { ar }\end{array}$ & 1.030 & .189 & .663 & 5.459 & .000 \\
\hline
\end{tabular}

a. Dependent variable: Competitive advantage

Sumber: Data Primer yang diolah, tahun 2016

Dalam analisis jalur model persamaan yang digunakan adalah dari bentuk standardized koefisien, sehingga diperoleh persamaan sebagai berikut :

$$
Y_{1}=0,664 X
$$

Koefisien variabel orientasi pasar $(X)$ memiliki arah positif. Hal ini berarti bahwa peningkatan orientasi pasar akan 
meningkatkan competitive advantage. Model persamaan I tersebut digunakan untuk menguji hipotesis 1.

Hasil pengujian hipotesis 1 mengenai pengaruh orientasi pasar terhadap competitive advantage menunjukkan nilai $t_{\text {hitung }}=5,459>t_{\text {tabel }}=2,024(\mathrm{df}=\mathrm{n}-2=40-2$ $=38, \alpha=0,05$, uji satu pihak), dengan angka signifikansi $0,001<\alpha=0,05$ (signifikan). Dengan demikian hipotesis 1 menunjukkan bahwa orientasi pasar berpengaruh positif terhadap competitive advantage.

Model Jalur II orientasi pasar $\left(\mathrm{X}_{1}\right)$ dan competitive advantage $\left(\mathrm{Y}_{1}\right)$ terhadap kinerja pemasaran $\left(Y_{2}\right)$.

Persamaan II menguji pengaruh orientasi pasar dan competitive advantage terhadap kinerja pemasaran, sehingga diperoleh model persamaan sebagai berikut:

Tabel Persamaan model II

\begin{tabular}{|c|c|c|c|c|c|c|}
\hline & & \multicolumn{2}{|c|}{$\begin{array}{l}\text { Unstandardized } \\
\text { Coefficients }\end{array}$} & $\begin{array}{r}\text { Standardiz } \\
\text { ed Coefficients } \\
\end{array}$ & \multirow[b]{2}{*}{$\mathrm{t}$} & \multirow[b]{2}{*}{ Sig. } \\
\hline \multicolumn{2}{|c|}{ Model } & B & Std. Error & Beta & & \\
\hline \multirow[t]{3}{*}{1} & (Constant) & 5.335 & 1.400 & & 3.811 & .001 \\
\hline & Orientasi Pasar & .373 & .179 & .309 & 2.084 & .044 \\
\hline & $\begin{array}{l}\text { Competitive } \\
\text { antage }\end{array}$ & .384 & .115 & .495 & 3.337 & .002 \\
\hline
\end{tabular}

a. Dependent variable: Kinerja pemasaran

Sumber: Data Primer yang diolah, tahun 2016

Dalam analisis jalur model persamaan yang digunakan adalah bentuk standardized koefisien, sehingga diperoleh persamaan sebagai berikut:

$$
Y_{2}=0,309 X+0,495 Y_{1}
$$

\section{Pengujian Hipotesis $\mathbf{2}\left(\mathbf{H}_{\mathbf{2}}\right)$}

Hasil pengujian hipotesis 2 mengenai pengaruh competitive advantage terhadap kinerja pemasaran menunjukkan nilai $t_{\text {hitung }}=$ $3,337>t_{\text {tabel }}=2,024(d f=n-2=40-2=38, \alpha$ $=0,05$, uji satu pihak), dengan angka signifikansi 0,002 < $\alpha=0,05$ (signifikan). Dengan demikian maka hipotesis 2 bahwa competitive advantage berpengaruh positif terhadap kinerja pemasaran.

\section{Pengujian Hipotesis $\mathbf{3}\left(\mathbf{H}_{3}\right)$}

Hasil pengujian hipotesis 3 mengenai pengaruh orientasi pasar terhadap kinerja pemasaran menunjukkan nilai $t_{\text {hitung }}=2,084>$ $t_{\text {tabel }}=2,024(\mathrm{df}=\mathrm{n}-2=40-2=38, \alpha=$ 0,05 ,uji satu pihak), dengan angka signifikansi $0,044<\alpha=0,05$ (signifikan). Dengan demikian maka hipotesis 3 bahwa orientasi pasar berpengaruh positif terhadap kinerja pemasaran.

Analisis jalur pengaruh orientasi pasar $\left(\mathrm{X}_{1}\right)$, terhadap kinerja pemasaran $\left(\mathrm{Y}_{2}\right)$ melalui competitive advantage $\left(\mathrm{Y}_{1}\right)$.

Analisis regresi orientasi pasar (OR), competitive advantage (CA) terhadap kinerja pemasaran (KP) dapat dijelaskan berdasarkan tabel 4.43. Berdasarkan tabel tersebut dapat diketahui bahwa koefisien regresi (beta) atau $\beta_{2}=0,508$, dan $\beta_{3}=0,238$ sehingga dapat

JIMFE (Jurnal Ilmiah Manajemen Fakultas Ekonomi)

Volume 2 No. 2 Tahun 2016, Hal. 58-68 
disusun persamaan regresi (jalur I) sebagai berikut:

$$
K P=0,3090 P+0,495 C A+e_{2}
$$

Dengan demikian dapat diketahui besarnya masing-masing pengaruh:

1. $\mathrm{OP} \longrightarrow \mathrm{KP}$ atau $\mathrm{p2}=0,309$ (bertanda positif)

Orientasi pasar (OP) berdasarkan positif terhadap kinerja pemasaran (KP), hal ini dapat diintrepretasikan bahwa semakin tinggi orientasi pasar maka semakin tinggi pula kinerja pemasaran.

2. $\mathrm{CA} \longrightarrow \mathrm{KP}$ atau $\mathrm{p3}=0,495$ (bertanda positif)

Competitive advantage (CA) berdasarkan positif terhadap kinerja pemasaran (KP), hal ini dapat diintrepretasikan bahwa semakin tinggi competitive advantage maka semakin tinggi pula kinerja pemasaran.

Berdasarkan hasil analisis path (jalur) I dan II dapat dilakukan analisis pengaruh orientasi pasar (OP), terhadap kinerja pemasaran (KP), dengan competitive advantage (CA), variabel mediasi (antara) sebagai berikut:

Persamaan regresi jalur I:

$C A=0,63 O P+e_{1}$
Dengan demikian nilai $p 1=0,663$

Persamaan regresi jalur II:

$K P=0,309 O P+0,495 C A+e_{2}$

Besarnya masing-masing pengaruh:

1. $\mathrm{CA} \rightarrow \mathrm{KP}$ sebesar $\mathrm{p2}=0,495$

2. $\mathrm{OP} \longrightarrow \mathrm{KP}$ sebesar $\mathrm{p} 4=0,309$

Sehingga dapat dijelaskan bahwa pengaruh orientasi pasar terhadap kinerja pemasaran dengan competitive advantage sebagai variabel mediasi:

$$
\begin{aligned}
& \mathrm{OP} \longrightarrow \mathrm{CA} \longrightarrow \mathrm{KP} \text { atau } \\
& \mathrm{p} 4=\mathrm{p} 1 \times \mathrm{p} 2=0,663 \times 0,495=0,328
\end{aligned}
$$

Pengaruh $\mathrm{p} 4=0,328>\mathrm{p} 4=0,309$, hal ini membuktikan hipotesis $4(\mathrm{H} 4)$ bahwa variabel competitive advantage (CA) sebagai variabel mediasi dari pengaruh orientasi pasar(OP) terhadap kinerja pemasaran (KP) berpengaruh positif. Dengan demikian maka hipotesis $4(\mathrm{H} 4)$ bahwa orientasi pasar berpengaruh positif terhadap kinerja pemasaran dengan competitive advantage sebagai variabel mediasi terbukti.

Selanjutnya dari model persamaan I dan model persamaan II dapat ditampilkan model diagram jalur sebagai berikut:

Gambar 1. Model Diagram Jalur

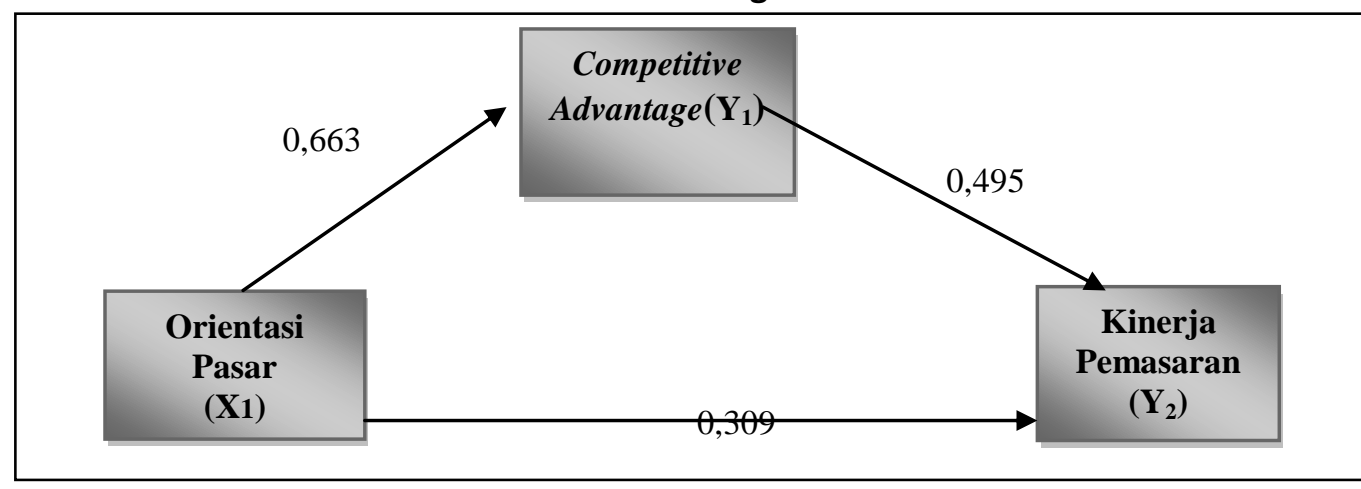

JIMFE (Jurnal Ilmiah Manajemen Fakultas Ekonomi) Volume 2 No. 2 Tahun 2016, Hal. 58-68 


\section{PENUTUP}

Pada prinsipnya penelitian ini bertujuan untuk mencari jawaban terhadap rumusan masalah yang telah dikemukakan pada bagian sebelumnya yaitu untuk mengetahui pengaruh orientasi pasar, dan adaptabilitas lingkungan, melalui competitive advantage terhadap kinerja pemasaran.

Hasil penelitian memperlihatkan bahwa pemilik UKM batik senantiasa aktif dalam mencari informasi yang terbaru seputar batik semarangan untuk memenuhi keinginan para pelanggan yang cepat berubah. Kemudian pemilik UKM batik senantiasa aktif dalam mencari informasi tentang hal yang berkaitan dengan motif, corak khas, atau desain batik semarangan dari pesaing lainnya dan pemilik UKM batik senantiasa aktif dalam berkoordinasi dengan baik antar fungsi di dalam suatu usaha, untuk melayani keinginan para pelanggan yang cepat berubah. Maka dapat disimpulkan bahwa orientasi pasar pada UKM produk unggulan Sentra Batik Semarangan di Kota Semarang adalah tinggi sehingga berdampak pada competitive advantage, dapat dilihat dari adanya pengaruh positif antara orientasi pasar dan competitive advantage,

Hal ini sejalan dengan penelitian terdahulu oleh Uncles (2000:1) yang mengartikan orientasi pasar sebagai suatu proses dan aktivitas yang berhubungan dengan penciptaan dan pemuasan pelanggan dengan cara terus menilai kebutuhan dan keinginan pelanggan. Apabila dibandingkan dengan penelitian terdahulu, orientasi pelanggan (customer orientation) diartikan sebagai pemahaman yang memadai terhadap pembeli sasaran sehingga superior value dapat diberikan secara terus-menerus (Narver dan Slater, 1990:6).

Keunggulan bersaing menurut Porter (2007:124) adalah kemampuan suatu perusahaan untuk meraih keuntungan ekonomis di atas laba yang mampu diraih oleh pesaing di pasar dalam industri yang sama. Hasil penelitian memperlihatkan bahwa hasil para pengrajin UKM produk unggulan Sentra Batik Semarangan di Kota Semarang berbeda dibandingkan dengan batik para pesaing terkait dengan kegiatan produksi, misalnya bahan kain yang dipakai dan pewarna yang dipakai. Harga batik semarangan juga dapat bersaing dibandingkan dengan harga batik para pesaing terkait ukuran panjang dan lebarnya kain batik yang dihasilkan sehingga mempengaruhi harga jualnya. Kemudian batik semarangan yang dihasilkan jarang djumpai di pasar terkait dengan ciri khas corak batik semarangan dan produksi batik lainnya yang tidak sama. Selain itu, batik semarangan yang dihasilkan tidak mudah ditiru dibandingkan dengan batik para pesaing karena adanya hak paten untuk tiap motif yang dihasilkan para pengrajin batik misalnya motif flora dan fauna, motif historis, dan motif kuliner Kota Semarang. Oleh karena itu dapat disimpulkan pula bahwa competitive advantage pada UKM produk unggulan Sentra Batik Semarangan di Kota Semarang adalahtinggi sehingga berdampak pada kinerja pemasaran yang dibuktikan dengan adanya pengaruh positif antara competitive advantage dan kinerja pemasaran. Hal ini sejalan dengan penelitian terdahulu oleh Ferdinand (2006:45-46) yang menyatakan bahwa suatu kinerja perusahaan akan terbagi menjadi kelompok kinerja dalam studi yang dikembangkan mengenai kinerja perusahaan yang secara spesifik didimensikan melalui kinerja pemasaran.

Hasil penelitian ini menunjukkan bahwa orientasi pasar berpengaruh positif terhadap competitive advantage dan selanjutnya akan berpengaruh terhadap kinerja pemasaran oleh karena itu saran dari hasil penelitian ini adalah perlunya peningkatan orientasi pasar melalui:

a. Meningkatkan keaktifan dalam mencari info-info terbaru yang menjadi trend, atau kegemaran

JIMFE (Jurnal Ilmiah Manajemen Fakultas Ekonomi)

Volume 2 No. 2 Tahun 2016, Hal. 58-68 
konsumen sekarang untuk motif batiknya.

b. Perlunya selalu meningkatkan koordinasi antar sesama pengrajin, misalnya aktif dalam beberapa pertemuan rutin yang membahas seputar batik semarangan.

Kemudian perlunya peningkatan competitive advantage melalui:

a. Pemilik UKM produk unggulan Sentra Batik Semarangan selalu menggali potensi apa yang menjadi ciri khas atau keunikkan motif batik semarangan.

b. Batik semarangan memiliki tema atau motif batik yang beranekaragam yang diangkat dari cerita, kuliner, flora, fauna yang hanya ada di Kota Semarang sehingga hal itu menjadi daya tariknya tersendiri.

\section{DAFTAR PUSTAKA}

Calantone, Roger, J. et al. 1994. Examining the Relationship netween Degree of Innovation and New Product Success. Journal of Business Research. Vol 30, No.2, p.143-148.

Ferdinand, Augusty. 2006. Sustainable Competitive Advantage. Semarang: Badan Penerbit Universitas Diponegoro. 2000. Manajemen Pemasaran: Sebuah Pendekatan Strategik, Research Paper Series No.1. Semarang: Badan Penerbit Universitas Diponegoro.

Kohli, A.K., \& Jaworski, B.J. 1993. Market Orientation: Antecedents and Consequences. Journal of Marketing. 57(July) p.55-70.

Lamb, Jr., Charles., and Hair, Jr., Joseph, F., \& Mc Daniel Carl. 1998. Pemasaran. Buku I. Jakarta: Salemba Empat.

Morrison, A., and Roth, K. 1992. Business Level Competitive Strategy: Contingency Link to
Internationalization. Journal of Management. 18.3,p 473-488.

Narver, J.C., \& Slater, S.F. 1990. The Effect of Market Orientation on Product Innovation. Journal of Marketing. p.2035.

Porter, Micheal., E. 2007. Strategi Bersaing (Competitive Advantage). Tangerang: KARISMA Publising Group.

Sarwono, Jonathan. 2007. Analisis Jalur Untuk Riset Bisnis dengan SPSS. Yogyakarta: Penerbit ANDI Yogyakarta.

Sugiyono. 1999.Metodologi Penelitian Bisnis. Bandung: Penerbit Alfabeta.

Uncles, Mark. 2000. Market Orientation. Australian Journal of Management. Vol.25,No.2. 